\title{
Direct Innervation and Modulation of Orexin Neurons by Lateral Hypothalamic LepRb Neurons
}

\author{
Gwendolyn W. Louis, ${ }^{1,2}$ Gina M. Leinninger, ${ }^{1}$ Christopher J. Rhodes, ${ }^{3}$ and Martin G. Myers, Jr ${ }^{1,2}$ \\ ${ }^{1}$ Division of Metabolism, Endocrinology, and Diabetes, Department of Internal Medicine, and ${ }^{2}$ Department of Molecular and Integrative Physiology, \\ University of Michigan, Ann Arbor, Michigan 48109, and ${ }^{3}$ Kovler Diabetes Center, University of Chicago, Chicago, Illinois 60637
}

Leptin, the adipose-derived hormonal signal of body energy stores, acts via the leptin receptor (LepRb) on neurons in multiple brain regions. We previously identified LepRb neurons in the lateral hypothalamic area (LHA), which are distinct from neighboring leptinregulated melanin-concentrating hormone $(\mathrm{MCH})$ - or orexin $(\mathrm{OX})$-expressing cells. Neither the direct synaptic targets of LHA LepRb neurons nor their potential role in the regulation of other LHA neurons has been determined, however. We thus generated several adenoviral and transgenic systems in which cre recombinase promotes the expression of the tracer, WGA (wheat germ agglutinin), and used these in combination with LepRb ${ }^{\text {cre }}$ mice to determine the neuronal targets of LHA LepRb neurons. This analysis revealed that, although some LHA LepRb neurons project to dopamine neurons in the ventral tegmental area, LHA LepRb neurons also densely innervate the LHA where they directly synapse with $\mathrm{OX}$, but not $\mathrm{MCH}$, neurons. Indeed, few other LepRb neurons in the brain project to the OX-containing region of the mouse LHA, and direct leptin action via LHA LepRb neurons regulates gene expression in OX neurons. These findings thus reveal a major role for LHA leptin action in the modulation of OX neurons, suggesting the importance of LHA LepRb neurons in the regulation of $\mathrm{OX}$ signaling that is crucial to leptin action and metabolic control.

\section{Introduction}

Leptin, a polypeptide hormone that is produced by adipocytes in proportion to fat content, signals the repletion of body energy stores to modulate neural processes linked to energy balance (Friedman, 2002; Elmquist et al., 2005; Morton et al., 2006; Myers et al., 2009). Circulating leptin decreases feeding and permits energy expenditure by activating the long-form of its receptor (LepRb) in the brain (Cohen et al., 2001; de Luca et al., 2005). Numerous brain regions contain LepRb-expressing, leptinresponsive neurons-including the hypothalamus, where large numbers of LepRb neurons reside in the arcuate (ARC), ventromedial (VMH), dorsomedial (DMH), and ventral premammillary (PMv) nuclei, as well as the preoptic (POA) and lateral hypothalamic (LHA) areas (Elmquist et al., 1998; Dhillon et al., 2006; Donato et al., 2009; Myers et al., 2009; Scott et al., 2009). LepRb neurons are also found in midbrain sites including the ventral tegmental area (VTA) and dorsal raphe (DR), and

\footnotetext{
Received March 15, 2010; revised July 8, 2010; accepted July 9, 2010.

This work was supported by National Institutes of Health (NIH) Grants DK057768 and DK078056, grants from the American Diabetes Association and the American Heart Association, and the Marilyn H. Vincent Foundation (M.G.M.), and NIH Reproductive Studies Program Training Grant T32 HD7048 at the University of Michigan (G.W.L.). Core support was provided by the University of Michigan Cancer Center, NIH Grant CA46592, and the University of Michigan Diabetes Research and Training Center, NIH Grant DK20572. We thank members of the Myers Laboratory, especially Drs. Rebecca Leshan and Christa Patterson, for discussions and support throughout. We thank Yusong Gong for excellent technical assistance in the development of mouse models and adenoviral tracers. We thank Z.Z. Zhang for excellent technical assistance; we thank Amylin Pharmaceuticals for the generous gift of leptin; we thank Dr. Yoshihiro Yoshihara (RIKEN Brain Science Institute, Saitama, Japan) for the gift of the WGA plasmid, and Dr. Corrinne Lobe (Toronto, Ontario, Canada) for the iZAP plasmid.

Correspondence should be addressed to Dr. Martin G. Myers, Jr., Division of Metabolism, Endocrinology and Diabetes, Department of Medicine, University of Michigan Medical School, 5560 MSRB II/0678, 1150 West Medical Center Drive, Ann Arbor, MI 48109. E-mail: mgmyers@umich.edu.

DOI:10.1523/JNEUROSCI.1340-10.2010

Copyright $\odot 2010$ the authors $\quad 0270-6474 / 10 / 3011278-10 \$ 15.00 / 0$
}

brainstem nuclei, such as the nucleus of the solitary tract (NTS) (Fulton et al., 2006; Grill, 2006; Hommel et al., 2006; Figlewicz et al., 2007; Myers et al., 2009; Scott et al., 2009). Although LepRb neurons in the well studied ARC, including proopiomelanocortin (POMC)- and agouti-related protein (AgRP)-expressing cells, contribute importantly to energy balance, these neurons mediate only a fraction of overall leptin action (Balthasar et al., 2004; Dhillon et al., 2006; van de Wall et al., 2008; Myers et al., 2009), suggesting the importance of the many non-ARC LepRb neurons throughout the brain.

Although the medial basal hypothalamus (including the ARC) acts in conjunction with the brainstem to modulate satiety (Grill, 2006; Myers et al., 2009), a variety of data suggest roles for the LHA in controlling the incentive to feed, including by regulating the mesolimbic dopamine (DA) reward system (DiLeone et al., 2003; Harris et al., 2005; Kelley et al., 2005; Nestler, 2005). Indeed, several populations of LHA neurons have been implicated in the regulation of feeding and the mesolimbic DA system. In addition to GABAergic LHA LepRb neurons, which modulate the expression of tyrosine hydroxylase $(T h)$ (the enzyme that catalyzes the rate-limiting step in DA production) in the mesolimbic DA system in response to leptin (Leinninger et al., 2009), the LHA contains populations of widely projecting neurons that express the neuropeptides orexin (OX) or melanin-concentrating hormone $(\mathrm{MCH})$. Among their other roles, LHA OX neurons project to the VTA, where OX controls drug and food reward; $\mathrm{MCH}$ neurons project to the striatum to modulate similar parameters (DiLeone et al., 2003; Harris et al., 2005; Sharf et al., 2010). Leptin decreases MCH action by inhibiting Mch expression and blunting endocannabinoid-mediated depolarizationinduced suppression of inhibition on $\mathrm{MCH}$ neurons ( $\mathrm{Qu}$ et al., 
1996; Jo et al., 2005). The modulation of OX neurons by leptin appears more complex: On one hand, leptin inhibits the firing of OX neurons in slice preparations and blocks the fasting-induced activation of OX neurons detected by c-fos immunostaining in vivo (Mieda and Yanagisawa, 2002; Yamanaka et al., 2003; Funato et al., 2009). Conversely, leptin promotes Ox mRNA expression, and $\mathrm{OX}$ signaling via the OX2R contributes to leptin action on energy balance (Tritos et al., 2001; Mieda and Yanagisawa, 2002; Yamanaka et al., 2003; Funato et al., 2009). Thus, although leptin inhibits the activity of OX neurons, leptin also promotes $O x$ expression and chronic OX signaling functions in concert with leptin action.

The neural mechanisms by which leptin modulates LHA neurons, such as those expressing $\mathrm{OX}$ and $\mathrm{MCH}$, and the potential interaction of LHA LepRb neurons with these neurons (as well as neurons in the VTA and elsewhere) remain unclear. To illuminate these issues, we generated and used several genetic tools to specifically examine LepRb neurons and their synaptic contacts. We show that LHA LepRb neurons directly innervate local OX, but not $\mathrm{MCH}$ neurons, and regulate gene expression in $\mathrm{OX}$ neurons.

\section{Materials and Methods}

Materials. Leptin was the generous gift of Amylin Pharmaceuticals.

Experimental animals. The generation of Lepr $r^{\text {cre/cre }}\left(\mathrm{LepRb}^{\mathrm{Cre}}\right)$ mice has been described previously; these animals were produced by intercrossing homozygous animals within our facility. Lepr ${ }^{\text {cre/cre }}$ mice were bred with Gt(ROSA)26-Sor ${ }^{\text {tm } 2 S h o}$ mice purchased from The Jackson Laboratory to generate double homozygous Lepr ${ }^{\text {cre/cre }}$;Gt(ROSA)26Sor ${ }^{\text {tm2Sho/tm2Sho }}$ (LepRb ${ }^{\text {EGFP }}$ ) mice, which were propagated by intercrossing (Leshan et al., 2009). C57BL/6 and Lep ${ }^{o b / o b}$ animals were purchased from The Jackson Laboratory.

For the generation of $i Z / W A P$ mice, the coding region for wheat germ agglutinin (WGA) was PCR-amplified from pBluescript II SK-WGA [a generous gift from Dr. Yoshihiro Yoshihara, RIKEN Brain Science Institute, Saitama, Japan (Hanno et al., 2003)] and inserted into the pCALL2IRES-hAP/cg vector (iZ/AP) [a generous gift from Dr. Corrine Lobe, Toronto, Ontario, Canada (Allen et al., 2006)] downstream of the CMV (cytomegalovirus) promoter-driven floxed $\beta$-geo cassette and upstream of an internal ribosome entry site (IRES)-alkaline phosphatase (AP) sequence. The resulting pCALL2-WGA/AP (iZ/WAP) plasmid was submitted to the University of Michigan transgenic core for production of transgenic embryonic stem cell clones. Four hundred eighty clones were screened for single copy number by quantitative PCR (qPCR) for neo sequences (Soliman et al., 2007) and also screened for $\beta$-gal expression via immunocytochemical staining (Roche). Five embryonic stem (ES) clones were expanded and rescreened, and three positive ES clones were injected into blastocysts and implanted into foster mothers. The resulting chimeric male progeny were bred to C57BL/ 6 females for the determination of germline transmission (by brown coat color) and confirmed via Southern blotting for the Neo cassette. Several $\mathrm{F}_{1}$ generation $i$ /WAP mice from each ES clone were perfused and screened for CNS $\beta$-gal expression by immunofluorescent staining using antibodies against $\beta$-gal, as detailed below. One $i Z / W A P$ line was determined to express the transgene throughout the CNS and was chosen for additional study. Although similar in genesis to previously reported transgenic animals (Braz et al., 2002), this new line demonstrates broader transgene expression in the brain, including the hypothalamus. Subsequent iZ/WAP litters were genotyped by conventional PCR using oligos derived from the original WGA sequence (forward, AATGAGAAAGATGATGAGCACC; reverse, AGGTTGTTCGGGCATAGCTT). iZ/WAP animals were bred with LepRb ${ }^{\text {EGFP }}$ mice (described above) to generate Lepr ${ }^{\text {cre/cre}}$; ROSA26 $6^{\text {EGFP/EGFP }} ;$ iZ/WAP (LepRb ${ }^{\text {EGFP/WGA }}$ ) animals for study.

Animals were housed in our colony in $12 \mathrm{~h}$ light/dark cycles and given ad libitum access to food and water. All care and procedures for mice were according to guidelines approved by the University of Michigan Committee on the Use and Care of Animals.
Perfusion, immunohistochemistry, and immunofluorescence. Perfusion and immunohistochemistry were performed essentially as described previously (Münzberg et al., 2007). Briefly, mice were deeply anesthetized with a lethal dose of intraperitoneal pentobarbital $(150 \mathrm{mg} / \mathrm{kg})$ and transcardially perfused with sterile PBS, and then $10 \%$ neutral buffered formalin. Brains were removed, postfixed overnight, and dehydrated in a $30 \%$ sucrose solution. Then brains were sectioned into $30 \mu \mathrm{m}$ coronal slices, collected in four series, and stored at $-20^{\circ} \mathrm{C}$ in cryoprotectant until additional use.

Brain sections were incubated in primary antibodies [goat anti- $\beta$ gal (1:3000; Biogenesis), chicken anti-green fluorescent protein (GFP) (1: 1000; Abcam), rabbit anti-MCH (1:1000; Phoenix Pharmaceuticals), goat or rabbit anti-OX (1:1000; Santa Cruz/Calbiochem), goat antiWGA (1:1000; Vector), mouse anti-TH (1:200, Millipore Bioscience Research Reagents), sheep anti- $\alpha$-MSH (1:5000; Millipore Bioscience Research Reagents), or rabbit anti-AgRP (1:1000; Phoenix)] overnight at $4^{\circ} \mathrm{C}$, and then visualized by immunofluorescent secondary detection using species-specific Alexa 488 or 568 antibodies (1:200; Invitrogen). Sections were mounted on slides and coverslipped with Prolong antifade mounting medium (Invitrogen).

Adenoviral tracers. The Ad-iZ/EGPFf adenoviral system to trace long axonal processes has been described previously (Leinninger et al., 2009; Leshan et al., 2009). For the generation of Ad-iN/WED, we first deleted the $\beta$-gal-encoding region of the $\beta$-geo fusion in pShuttle/iZ (Leinninger et al., 2009; Leshan et al., 2009) by PCR using the QuikChange kit (Stratagene), generating pShuttle/iN (thereby decreasing the size of the construct to promote proper viral packaging with larger inserts). The coding region of WGA, as above, along with an IRES element and the coding sequence for farnesylated dsRED (dsRedf), was then subcloned into the multiple cloning site of pShuttle/iN vector to generate pShuttle-iN/ WED. Vector DNA was purified, linearized and used to generate the cre-inducible WGA adenoviral vector (Ad-iN/WED). Concentrated adenoviral stocks were generated and purified as previously described (Morton et al., 2003; Leshan et al., 2009). Cre-dependent WGA expression from Ad-iN/WED was verified in vitro by immunocytochemical staining for WGA in infected HEK293 cells transfected with a vector encoding cre recombinase.

Site-specific LepRb tract-tracing experiments. For tract-tracing experiments, LepRb ${ }^{\text {Cre }}$ or LepRb ${ }^{\text {EGFP }}$ mice were anesthetized using isoflurane and placed in a stereotaxic apparatus. After exposing the skull, a guide cannula with stylet was lowered into LHA coordinates (from bregma) [anteroposterior (AP), - 1.34; mediolateral (ML), - 1.1; dorsoventral (DV), -5.1; OX field] or (AP, - 1.34; ML, -1.38 , DV, -5.1; lateral/ $\mathrm{MCH}$ field). The stylet was removed and replaced by an injector and either $50 \mathrm{nl}$ of $4 \%$ fluorogold (FG)-equivalent (Sigma-Aldrich) or 200$500 \mathrm{nl}$ of Ad-iZ/EGPFf or Ad-iN/WED was acutely injected, using a 500 $\mathrm{nl} \mathrm{Hamilton}$ syringe at a rate of $100 \mathrm{nl} / \mathrm{min}$. After $10 \mathrm{~min}$ to allow for absorption of tracer, the injector and cannula were removed, and the skull and the incision was sealed and sutured. Mice received presurgical and postsurgical analgesia (Buprenex; $150 \mu \mathrm{l}$ of $0.01 \mathrm{mg} / \mathrm{ml}$ ) and were individually housed for 2-5 d (FG-mediated retrograde tracing) or $5 \mathrm{~d}$ (Ad-iZ/EGPFf and Ad-iN/WED-mediated anterograde tracing) before perfusion and processing. Five farnesylated enhanced green fluorescent protein (EGFPf)-injected animals and four Ad-iN/WED-injected animals displayed injection sites confined within the LHA, as well as substantial WGA expression, and were thus selected for additional analysis.

Data collection and analysis. Slides were analyzed via light or fluorescent microscopy using an Olympus BX-51 microscope with filters for Alexa 488 or Alexa 568 and images taken with software as previously described (Münzberg et al., 2007). Using Adobe Photoshop software (Adobe Systems), images were overlaid in different RGB channels to reveal single- or double-labeled cells. Confocal images were captured with an Olympus FV-500.

Leptin treatment to assess changes in LHA gene expression. Two cohorts of adult male $L e p^{o b / o b}$ mice ( $n=20$ each cohort) were obtained: the first cohort for systemic (intraperitoneal) treatment with sterile PBS or leptin $(5 \mathrm{mg} / \mathrm{kg}$ ) and the second for the chronic implantation of cannulae into the LHA (AP, $-1.30 ; \mathrm{ML},-1.12$; DV, -4.15 ), as described previously (Leinninger et al., 2009). Briefly, cannulae with dummy injector were 
stereotaxically inserted and affixed into the LHA site. After surgery, mice were single housed and checked daily for food intake and body weight to monitor their recovery. After $7-10 \mathrm{~d}$ of recovery, mice were treated with 250 $\mathrm{nl}$ of either sterile PBS or leptin $(0.001 \mathrm{ng} / \mathrm{nl})$ $(=0.25 \mathrm{ng})$. Both cohorts were treated with either PBS or leptin every $12 \mathrm{~h}$ for $24 \mathrm{~h}$, with the final dose given $2 \mathrm{~h}$ before killing for a total of three injections (for a total of $0.75 \mathrm{ng}$ of leptin) over $26 \mathrm{~h}$ of treatment. We previously selected this dosing regimen to approximate physiologic leptin concentrations in the volume of distribution of the LHA, to avoid the detectable spread of leptin to other hypothalamic regions, and to provide long enough treatment to permit the detection of changes in gene expression (Leinninger et al., 2009). After treatment, specific nuclei of the brain were microdissected as described previously (Leinninger et al., 2009).

RNA extraction and analysis of gene expression by $q$ PCR. LHA and ARC were microdissected and snap frozen for later processing and analysis of mRNA expression by quantitative reverse transcription (RT)-PCR (as previously described) (Leinninger et al., 2009). Briefly, RNA was extracted using Trizol (Invitrogen) and converted to cDNA using the SuperScript First-Strand Synthesis System for RT-PCR (Invitrogen). cDNA was analyzed in triplicate via qRT-PCR for Gapdh and neuropeptide gene expression [as previously described (Bates et al., 2003) or as supplied by Applied Biosystems] using an Applied Biosystems 7500. Gene expression was normalized to Gapdh expression and relative mRNA expression was calculated via the $2^{-\Delta \Delta \mathrm{Ct}}$ method. Cannulated mice were also normalized to the contralateral (unperturbed) side. Statistical significance was determined by Student's $t$ test as computed with Excel.

\section{Results}

Molecular tools to examine neural mechanisms of leptin action As the identification of LepRb neurons by direct detection of LepRb remains problematic, we previously generated LepRb ${ }^{\text {EGFP }}$ reporter mice, in which $L_{e p r}{ }^{c r e}$-driven cre recombinase expression within LepRb neurons mediates the expression of EGFP from the ROSA26-EGFP allele to reveal LepRb neurons (Leinninger et al., 2009; Leshan et al., 2009; Myers et al., 2009) (Fig. $1 A-C)$. Although EGFP expression in LepRb ${ }^{\text {EGFP }}$ reporter mice reveals that LHA LepRb neurons are distinct from MCH and OX neurons (Fig. 1 B,C) (Leinninger et al., 2009), leptin is known to modulate the activity and gene expression of $\mathrm{MCH}$ and $\mathrm{OX}$ neurons (Qu et al., 1996; Tritos et al., 2001; Mieda and Yanagisawa, 2002; Yamanaka et al., 2003; Jo et al., 2005; Funato et al., 2009), suggesting that LepRb neurons synapse with these LHA neurons to regulate them. To permit the examination of projections from LepRb neurons and the identification of their synaptic targets, we thus generated transgenic animals and adenoviral systems to promote the expression of EGFPf [which is targeted to the membrane and thus more robustly reveals axonal projections than standard cytoplasmic EGFP (Zylka et al., 2005)] or WGA [a lectin that passes transynaptically to accumulate in target neurons (Braz et al., 2002; Hanno et al., 2003)] (Fig. 1A).

\section{LepRb ${ }^{\text {EGFP/WGA }}$ mice reveal LHA neurons that lie in synaptic contact with LepRb neurons}

To examine whether LepRb neurons lie in synaptic contact with MCH and OX neurons in the LHA, we generated the $i Z / W A P$ transgenic mouse line, in which cre recombinase promotes the expression of WGA in cre-expressing neurons. We bred $i Z / W A P$ to the Lepr ${ }^{\text {cre }}$;ROSA26-EGFP (LepRb ${ }^{\text {EGFP }}$ ) background to produce LepRb ${ }^{\text {EGFP/WGA }}$ animals in which LepRb neurons express EGFP and WGA, and in which WGA accumulates in non-EGFP-expressing neurons that lie in synaptic contact with LepRb neurons (Figs. 1 A, 2). Although an IRES and the sequence encoding AP was inserted into our construct downstream of WGA, the IRES-mediated expression of AP proved to be insufficient to mediate its detection in the CNS (data not shown), necessitating the use of cre-inducible EGFP to label primary LepRb neurons.

Staining for WGA in LepRb ${ }^{\text {EGFP }}$ mice or in $i Z / W A P$ mice not containing a cre allele revealed no detectable WGA immunoreactivity (IR) (data not shown), but numerous strongly WGAimmunoreactive (as well as GFP-immunoreactive) neurons were detected in the hypothalamus of LepRb ${ }^{\text {EGFP/WGA }}$ mice, including in the LHA (Fig. 2A-L). Costaining for GFP/LepRb and WGA revealed neurons within the LHA that contained both GFP- and WGA-immunoreactive neurons, representing WGA-expressing LHA LepRb neurons (Fig. 2A-D, arrows). Additionally, we detected many WGA-immunoreactive cells that were devoid of GFP IR, representing neurons that lie in synaptic contact with LepRb neurons but that are not themselves LepRb neurons (Fig. $2 A-D$, arrowheads). Also, in using these LepRb ${ }^{\text {EGFP/WGA }}$ mice, we explored whether LepRb neurons communicate with $\mathrm{MCH}$ and/or OX neurons by examining the colocalization of WGA with either $\mathrm{MCH}$-immunoreactive or $\mathrm{OX}$-immunoreactive neurons (Fig. $2 E-H, I-L$, respectively). This analysis revealed that $\sim 10 \%$ of $\mathrm{MCH}$ and $30 \%$ of OX neurons also contained strong WGA IR. Thus, although MCH and OX neurons in the LHA do 

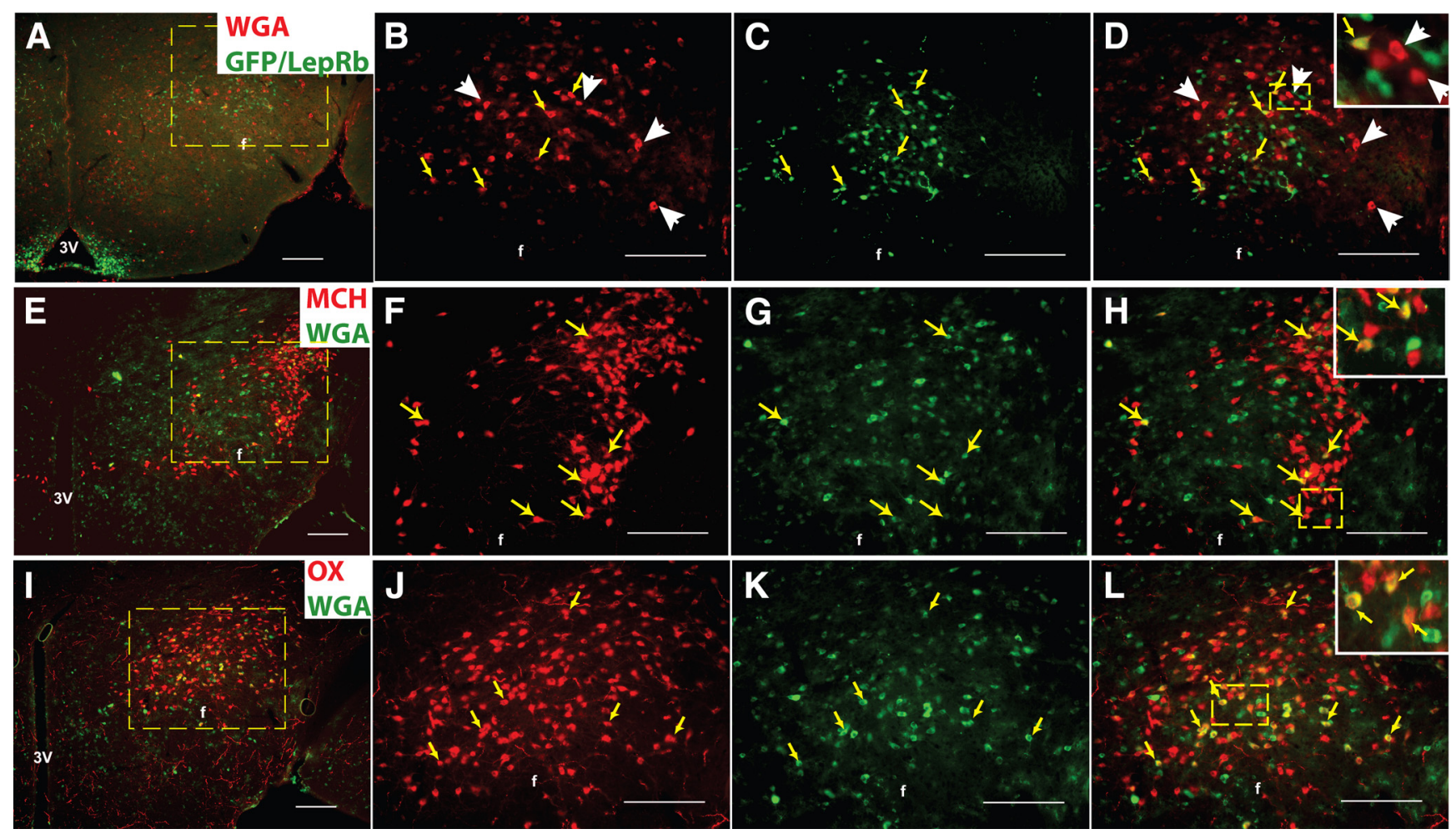

Figure 2. LepRb EGFP/WGA mice reveal LepRb-expressing cells and their projection targets in the LHA. A, Immunofluorescent detection of WGA (red) and GFP/LepRb (green) in the LHA of LepRb ${ }^{\text {EGFP/WGA }}$ mice. $\boldsymbol{E}, \boldsymbol{I}$, Immunofluorescent detection of WGA (green) $(\boldsymbol{E}, \boldsymbol{I})$ and MCH (red) $(\boldsymbol{E})$ and $\mathrm{OX}$ (red) (I) in the LHA of LepRb ${ }^{\mathrm{EGFP} / \mathrm{WGA}}$ mice. $\boldsymbol{B}-\boldsymbol{D}, \boldsymbol{F}-\boldsymbol{H}$, and $\boldsymbol{J}-\boldsymbol{L}$ show enlarged images of the boxed regions of $\boldsymbol{A}, \boldsymbol{E}$, and $\boldsymbol{I}$, respectively. $\boldsymbol{B}, \boldsymbol{F}$, and $\boldsymbol{J}$ show red channel only; $\boldsymbol{C}, \boldsymbol{G}$, and $\boldsymbol{K}$ show green channel only; and $\boldsymbol{D}, \boldsymbol{H}$, and $\boldsymbol{L}$ show merged images. Insets, Higher magnification view of boxed regions. Yellow arrows, Representative colabeled cells; white arrowheads, single-labeled cells. Scale bars, $200 \mu \mathrm{m}$. 3V, Third ventricle; f, fornix.

not express LepRb to directly respond to leptin, they represent synaptic targets of LepRb neurons, consistent with the previously described regulation of $\mathrm{OX}$ and $\mathrm{MCH}$ neurons by leptin $(\mathrm{Qu}$ et al., 1996; Yamanaka et al., 2003). Since WGA expression in LepRb ${ }^{\mathrm{EGFP} / W G A}$ mice is driven from a standard transgenic promoter, it is not clear whether the finding that not all of these neurons contain WGA indicates mosaic WGA expression in the LepRb neurons, or whether LepRb neurons only innervate a subset of $\mathrm{OX}$ and $\mathrm{MCH}$ neurons. Furthermore, since LepRb neurons throughout the brain express WGA, the analysis of LepRb ${ }^{\mathrm{EGFP} /}$ WGA mice does not identify the specific population of LepRb neurons that project onto $\mathrm{MCH}$ or OX neurons.

\section{Few extra-LHA LepRb neurons project to the dorsal perifornical LHA}

To identify brain regions containing LepRb neurons that might project onto neurons in the LHA, we injected the retrograde tracer, FG, into the LHA of LepRb ${ }^{\mathrm{EGFP}}$ mice (Fig. 3A) and analyzed these brains for regions containing FG and GFP IR (Fig. $3 B-F)$. FG was specifically injected into the dorsal perifornical LHA in the region containing LHA LepRb neurons (Fig. 3A). The majority of LHA LepRb neurons lie in the mid and caudal portion of the dorsal perifornical region of the LHA and are mostly codistributed with OX neurons (Fig. $1 C$ ). Several brain regions contained both LHA-projecting (FG-immunoreactive) and LepRb (GFP-immunoreactive neurons), including the VTA (Fig. 3C,D) and the POA (Fig. $3 E, F$ ), although only a few LepRb/GFP neurons in the VTA accumulated FG from the dorsal perifornical LHA. Little or no FG from this region of the LHA accumulated in ARC neurons (Fig. 3B). Consistently, few neuropeptide-immunoreactive projec- tions from ARC POMC and AgRP neurons are detected in the main OX field, but rather densely innervate the surrounding area (supplemental Fig. 1, available at www.jneurosci.org as supplemental material). We furthermore tested FG tracing from the region of the LHA lateral to the OX field, where MCH neurons are typically located (supplemental Fig. $2 \mathrm{~A}$, available at www.jneurosci.org as supplemental material). These injections yielded FG tracing to LepRb neurons in the NTS, DR, and the ARC (supplemental Fig. $2 B-D$, available at www.jneurosci.org as supplemental material). Overall, although LepRb neurons (including those from the ARC) innervate some portions of the LHA, these data reveal that few extra-LHA LepRb neurons project to the dorsal perifornical region of the LHA that contains LepRb and OX neurons, suggesting that LHA LepRb neurons might represent the primary LepRb neurons that innervate this area and the OX neurons contained therein.

\section{Innervation of the VTA and LHA by LHA LepRb neurons}

To more closely examine the potential innervation of the perifornical LHA by LHA LepRb neurons, we first injected the previously described Ad-iZ/EGFPf (Leinninger et al., 2009; Leshan et al., 2009) into LepRb ${ }^{\text {cre }}$ mice (Figs. $1 A, 4$ ), thus mediating the expression of EGFPf specifically in cre-expressing (i.e., LepRb) neurons. Since EGFPf is targeted to the membrane, it robustly reveals the axonal architecture of EGFPf-expressing cells. We thus injected Ad-iZ/EGFPf into the LHA of LepRb ${ }^{\text {cre }}$ mice (Fig. $4 \mathrm{~A}$ ), promoting the expression of EGFPf in LHA LepRb neurons, and analyzed the GFP-immunoreactive neurites within the LHA (Fig. $4 B, C$ ). Many of these neurites demonstrated the "beads on a string" appearance consistent with the presence of synapses, 

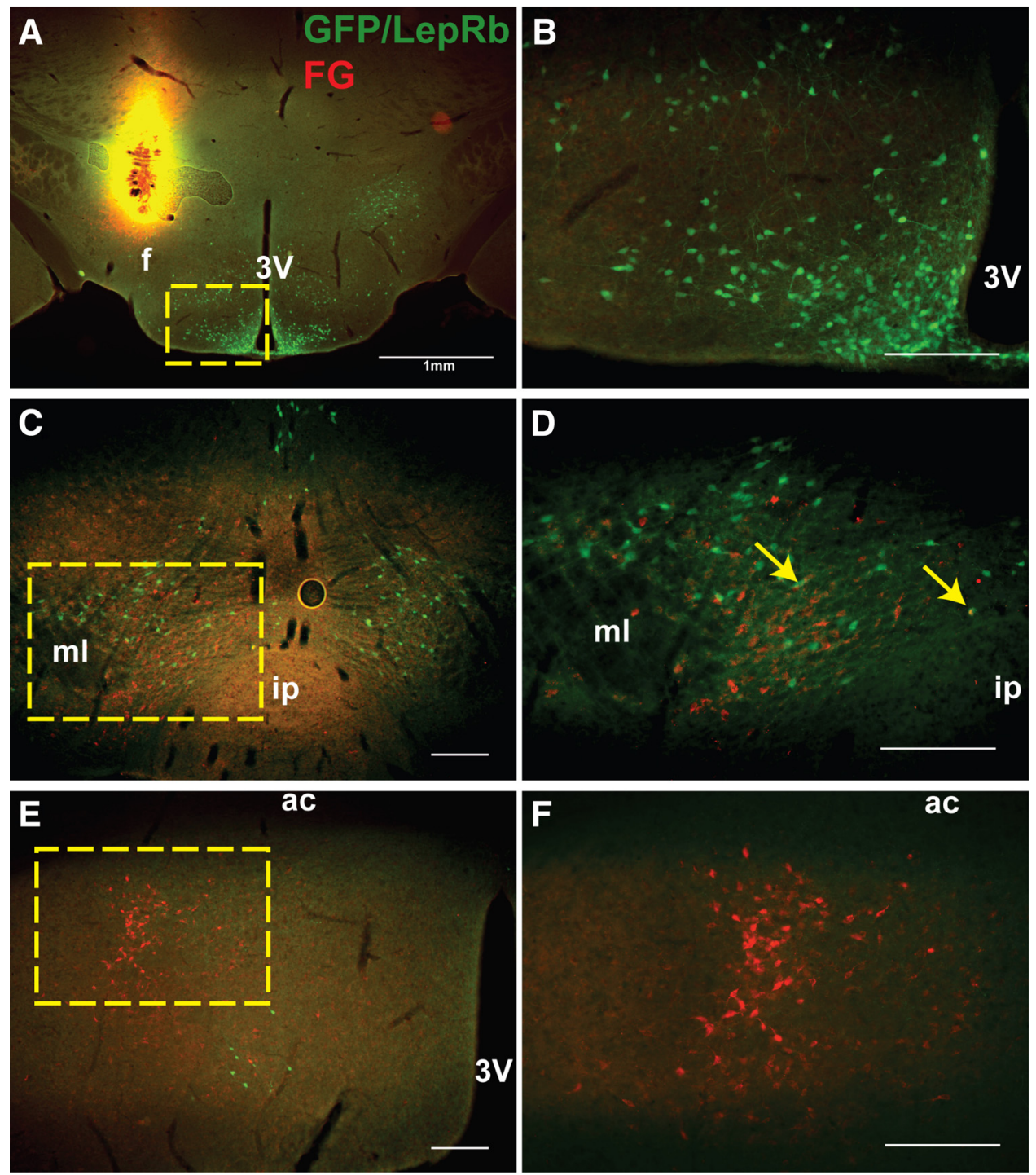

Figure 3. Retrograde tracing from the LHA OX field in LepRb ${ }^{\text {EGFP }}$ mice to determine potential presynaptic LepRb populations. The retrograde tracer, FG, was injected into the dorsal perifornical region of the LHA of LepRb ${ }^{\text {EGFP }}$ mice; after perfusion, the brains were processed for the immunofluorescent detection of GFP/LepRb (green) and FG (red). $\boldsymbol{A}$, View of the LHA injection site in a representative animal. $\boldsymbol{B}$, ARC. $\boldsymbol{C}, \boldsymbol{D}$, VTA. $\boldsymbol{E}, \boldsymbol{F}$, Lateral POA. $\boldsymbol{B}, \boldsymbol{D}$, and $\boldsymbol{F}$ are magnified images of boxed areas in $\boldsymbol{A}, \boldsymbol{C}$, and $\boldsymbol{E}$, respectively. Representative images from one of two animals with injection site restricted to the dorsal perifornical area are shown. Arrows, Representative colabeled cells. Scale bars, $200 \mu \mathrm{m}$ (unless otherwise noted). $3 \mathrm{~V}$, Third ventricle; $\mathrm{f}$, fornix; ip, intrapenduncular nucleus; ml, medial lemniscus; ac, anterior commissure.

similar to the appearance of LHA LepRb axons in more distant regions, such as the VTA (Fig. $4 D-F$ ). These data thus suggest that LHA LepRb neurons may innervate local, as well as distant, neurons. Furthermore, in analyzing the LHA for GFP IR and OX IR, we detect EGFP/LepRb fibers in close contact with OX neurons (Fig. $4 G-L$ ), suggesting that LHA LepRb neurons may innervate local OX neurons.

To reveal specific populations of neurons that lie in synaptic contact with LHA LepRb neurons, we generated the transsynaptic adenoviral tracer, Ad-iN/WED, to mediate the expression of a WGA/EGFP fusion protein in cre-expressing cells (Fig. 1A). Thus, site-specific injection of Ad-iN/WED to cre-expressing animals is expected to promote the expression of WGA/EGFP in anatomically restricted populations of cre-expressing neurons around the injection site and also effect WGA/EGFP accumulation in the synaptic targets of these cre-expressing neurons. Although Ad-iN/WED was also designed to express dsREDf to reveal the neurites of the cre-expressing cells, IRES-mediated
dsRedf expression was insufficient to enable its detection in in vitro tests or in vivo (data not shown).

We administered Ad-iN/WED into the LHA of LepRb ${ }^{\text {cre }}$ mice and perfused them for the detection of WGA IR after $5 \mathrm{~d}$. Intra-LHA administration of Ad-iN/WED produced WGA expression in the LHA of LepRb ${ }^{\text {cre }}$ mice (Fig. 5A,B); no WGA IR was detected after the injection of Ad-iN/WED in non-creexpressing mice, however (data not shown). We analyzed WGAimmunoreactive neurons in four LepRb ${ }^{\text {cre }}$ mice in which the injection sites were restricted to the dorsal perifornical area of the LHA (supplemental Fig. 3, available at www.jneurosci.org as supplemental material), where LHA OX and LepRb neurons are concentrated, and in which robust WGA expression was observed. To determine the neurons innervated by LHA LepRb neurons, we initially examined WGA accumulation in the LHA and the major extra-LHA projection site of LHA LepRb neurons, the VTA (Fig. 5C-F) (Leinninger et al., 2009). Although this analysis demonstrated the presence of copious WGA-immunoreactive 

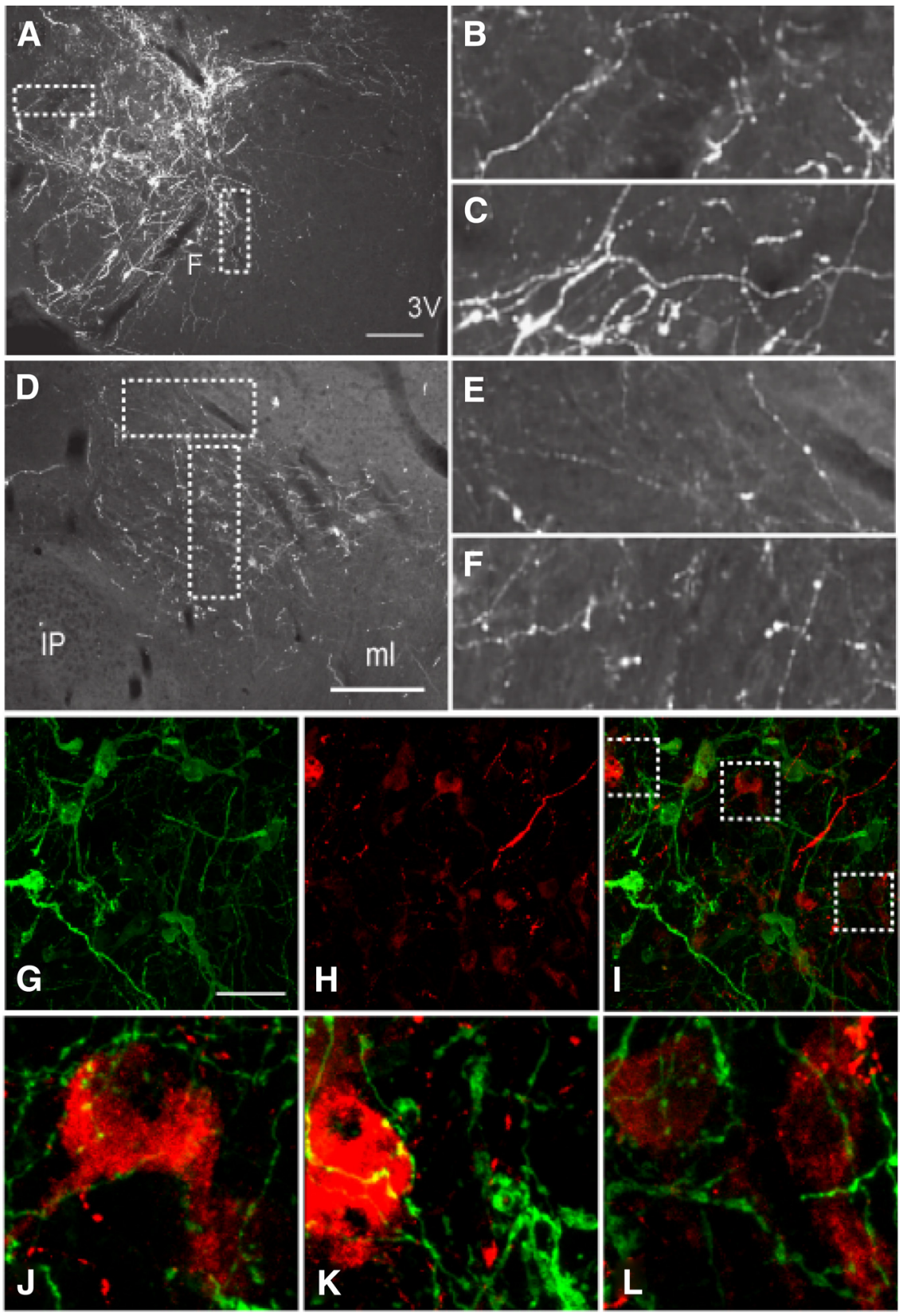

Figure 4. Ad-iZ/EGFPf injection to the LHA of LepRb ${ }^{\text {cre }}$ mice provides evidence for intra-LHA as well as intra-VTA synapses on projections from LHA LepRb neurons. $\boldsymbol{A}-\boldsymbol{F}$, Immunofluorescent detection of EGFPf in the LHA $(\boldsymbol{A}-\boldsymbol{C})$ and in the VTA (D-F). $\boldsymbol{B}$ and $\boldsymbol{C}$, and $\boldsymbol{E}$ and $\boldsymbol{F}$ represent digitally zoomed images of synaptic boutons in $\boldsymbol{A}$ and $\boldsymbol{D}$, respectively. $\boldsymbol{G}, \boldsymbol{H}$, Confocal images of EGFP/LepRb (green) $(\boldsymbol{G})$ and $0 X($ red) $(\boldsymbol{H})$ neurons within the LHA. $\boldsymbol{I}-\boldsymbol{L}$ represent merged images; $\boldsymbol{J}-\boldsymbol{L}$ are digitally magnified views of synaptic boutons from the boxed region in $I$. Scale bars: $A, D, 200 \mu \mathrm{m} ; \boldsymbol{G}$ (for $\mathbf{G}-\boldsymbol{L}$ ), $50 \mu \mathrm{m}$. 3V, Third ventricle; f, fornix; ip, intrapenduncular nucleus; ml, medial lemniscus.

neurons in the LHA, it revealed very few WGA-immunoreactive neurons in the VTA. Some of these VTA WGA-immunoreactive neurons colocalized with TH, suggesting that at least some LHA LepRb neurons directly innervate VTA DA neurons. Other distant regions, including the ARC, similarly contained few or no WGAimmunoreactive neurons (data not shown). Although these data are consistent with a direct synaptic connection between some LHA LepRb neurons and VTA DA targets, the paucity of detectable WGA-immunoreactive VTA neurons suggests that the WGA/ EGFP transgene expressed by Ad-iN/WED may poorly traverse synapses far removed from the primary WGA/EGFP-expressing neurons (Leinninger et al., 2009).
LHA LepRb neurons synapse with $\mathrm{OX}$, but not $\mathrm{MCH}$, neurons

To examine the potential innervation of local LHA neurons by LHA LepRb neurons, we examined the accumulation of WGA by $\mathrm{OX}$ and $\mathrm{MCH}$ neurons in the LHA of four LepRb ${ }^{\text {cre }}$ mice after the intraLHA injection of Ad-iN/WED. This analysis revealed the accumulation of WGA IR in numerous OX-immunoreactive neurons (Fig. $6 \mathrm{E}-\mathrm{H}$ ), but not $\mathrm{MCH}-$ immunoreactive neurons (Fig. 6A-D) (see also supplemental Fig. 4, available at www.jneurosci.org as supplemental material). Thus, LHA LepRb neurons lie in synaptic contact with OX neurons, but not $\mathrm{MCH}$ neurons. These data thus reveal that non-LHA LepRb neurons must mediate the effects of leptin on $\mathrm{MCH}$ neurons and also suggest a role for LHA LepRb neurons in the control of OX neurons by leptin.

\section{LHA leptin action regulates gene expression in OX neurons}

To determine the potential role for LHA LepRb neurons in the control of OX neurons in response to leptin, we examined the ability of LHA leptin to regulate these neurons. Previous data have demonstrated that leptin modulates OX neurons in multiple manners: systemic leptin administration promotes $O x$ mRNA expression (Fig. 7A) but also inhibits the fastingstimulated activation of OX neurons, as detected by c-fos IR (Tritos et al., 2001; Mieda and Yanagisawa, 2002; Yamanaka et al., 2003; Funato et al., 2009). Since our previous experience reveals that intraLHA cannulation interferes with the examination of LHA c-fos IR (data not shown), we chose to focus on the modulation of $\mathrm{OX}$ neuron gene expression in response to intra-LHA leptin infusion. We thus studied the regulation of ARC and LHA gene expression in response to systemic ( $5 \mathrm{mg} / \mathrm{kg}$, i.p.) (Fig. $7 A$ ) or intraLHA (0.25 ng) (Fig. 7B) leptin in Lep ${ }^{o b / o b}$ animals, in which the absence of endogenous leptin permits the sensitive examination of leptin action. We previously demonstrated the confinement of leptin action to the LHA using this small dose of intra-LHA leptin (Leinninger et al., 2009). Animals were treated with vehicle or leptin for $26 \mathrm{~h}$ before killing for the harvesting of microdissected ARC and LHA tissue and the preparation of RNA for the analysis of gene expression by qPCR. Leptin induces Socs3 expression in a cell-autonomous manner (Banks et al., 2000; Bjorbak et al., 2000) as well as directly promoting Pomc expression in ARC POMC neurons (Friedman, 2002; Elmquist et al., 2005; Morton et al., 2006; Myers et al., 2009); changes in Socs 3 and Pomc mRNA thus serve as a marker of direct leptin action in the ARC. Systemic leptin treatment significantly increased the expression of Pomc and Socs 3 in the ARC, as 


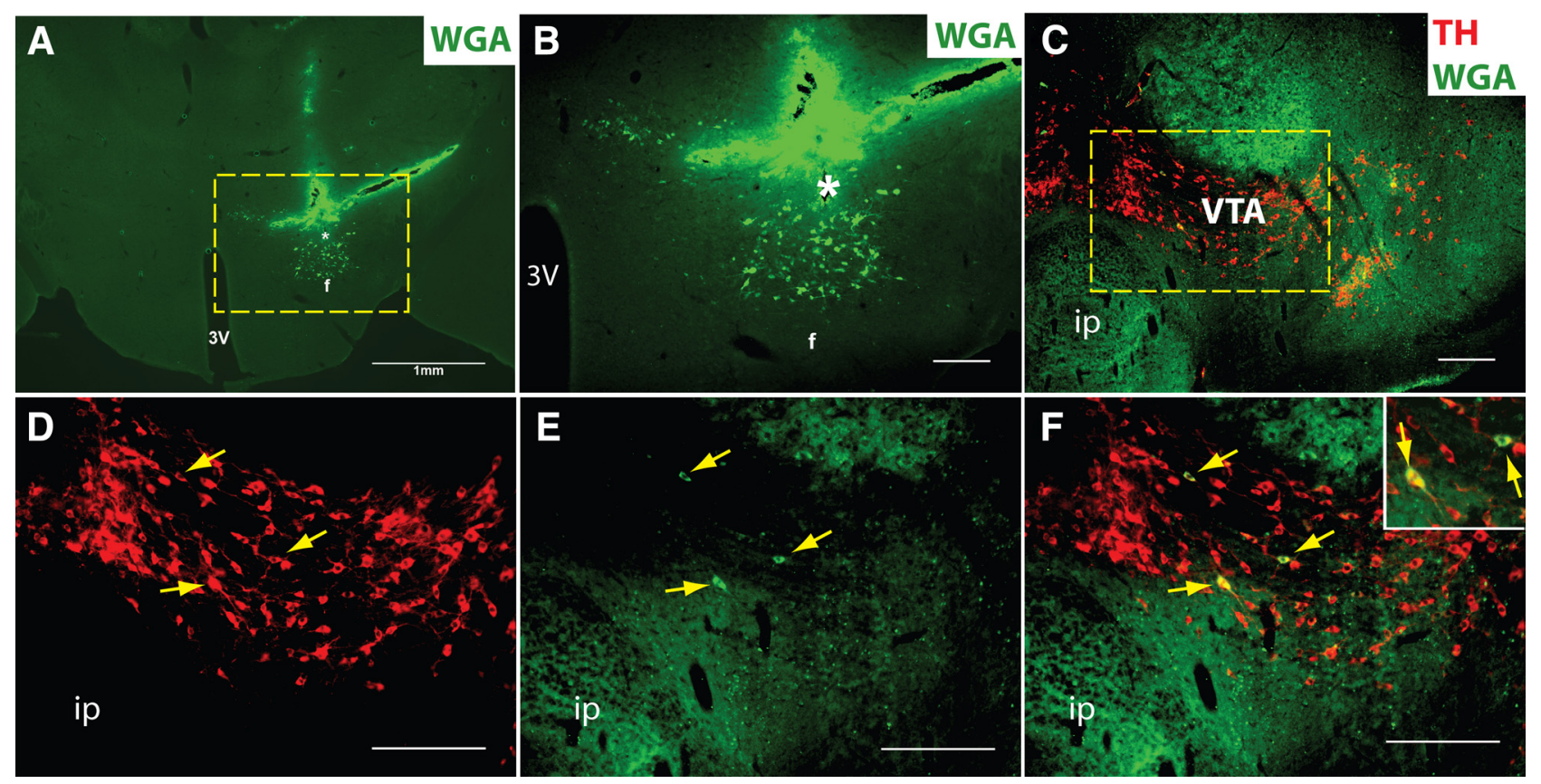

Figure 5. Modest accumulation of WGA in VTA relative to LHA neurons after Ad-iN/WED injection to the LHA of LepRb ${ }^{\text {cre }}$ mice. $A$, Immunofluorescent detection of a robust population of WGA-immunoreactive neurons (green) in the LHA of a representative intra-LHA Ad-iN/WED-injected LepRb ${ }^{\text {cre }}$ mouse. $\boldsymbol{B}$, Enlarged image of the boxed region in $\boldsymbol{A}$. $\boldsymbol{C}$, Detection of WGA (green) and a robust population of TH-immunoreactive neurons (DA; red) in the VTA. $\boldsymbol{D}-\boldsymbol{F}$ show single channel and merged enlarged images of the boxed region from $\boldsymbol{C}$. The asterisk (*) indicates injection site; arrows, representative colabeled cells. Scale bars, $200 \mu \mathrm{m}$ (unless otherwise noted). 3V, Third ventricle; f, fornix; ip, intrapenduncular nucleus.
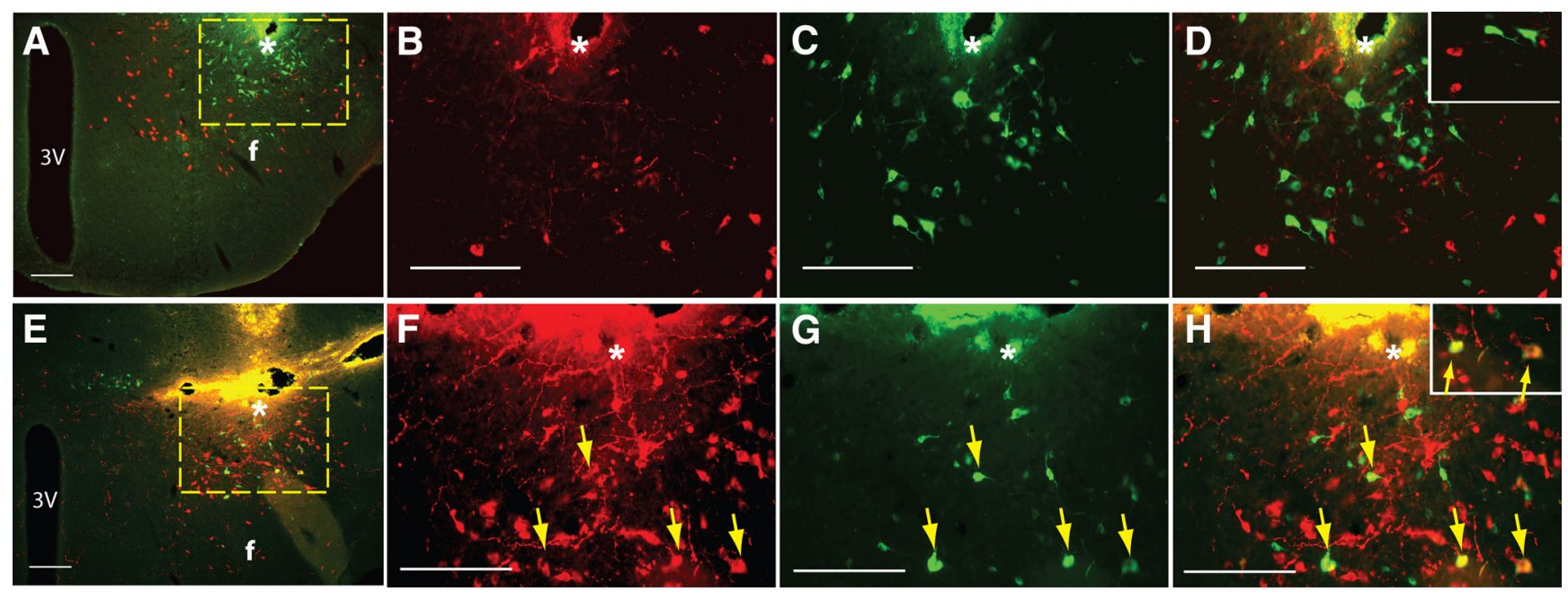

Figure 6. Local tracing of LepRb neurons and their synaptic targets in the LHA after Ad-iN/WED injection to the LHA of LepRb ${ }^{\text {cre }}$ mice. Immunofluorescent detection of WGA (green) $(A, E)$ and MCH (red) $(\boldsymbol{A})$ or OX (red) $(\boldsymbol{E})$ in the LHA after stereotaxic injection of Ad-iN/WED to the LHA. $\boldsymbol{B}-\boldsymbol{D}$ and $\boldsymbol{F}-\boldsymbol{H}$ show single channel and merged enlarged images of the boxed regions from $\boldsymbol{A}$ and $\boldsymbol{E}$, respectively. Insets, Digitally magnified view of labeled neurons. The asterisk (*) indicates injection site; arrows, colabeled cells. Scale bars, $200 \mu \mathrm{m}$. 3V, Third ventricle; f, fornix.

well as increasing the expression of $O x$ (by twofold) and neuronal activity-regulated pentraxin (Nptx2) (also known as Narp), which is coexpressed with OX in the LHA (Reti et al., 2002) (by $20 \%$ ) in the LHA (Fig. 7A). In contrast to the effects of systemic leptin, intra-LHA leptin failed to significantly modulate ARC Pomc or Socs3 gene expression, consistent with the predicted site specificity of intra-LHA leptin action and the lack of projections from LHA LepRb neurons to the ARC (Figs. 3B, 7B). Furthermore, intra-LHA leptin treatment failed to change LHA $M c h$ expression. In contrast, intra-LHA leptin promoted a dramatic increase in LHA $O x(\sim 25$-fold $)$ and $N p t x 2(\sim 4$-fold $)$ mRNA expression (Fig. 7B). Thus, leptin action via LHA
LepRb neurons robustly modulates gene expression in OX neurons, specifically.

\section{Discussion}

We have examined the innervation of specific populations of LHA neurons by LepRb neurons, revealing that, although both $\mathrm{OX}$ and $\mathrm{MCH}$ neurons receive synaptic contact from LepRb neurons, local LHA LepRb neurons project onto OX, but not $\mathrm{MCH}$, neurons. Consistent with the direct projection of LHA LepRb neurons onto local OX neurons, LHA leptin action robustly modulates gene expression in OX neurons, revealing the functional importance of this local circuit. We previously showed that 

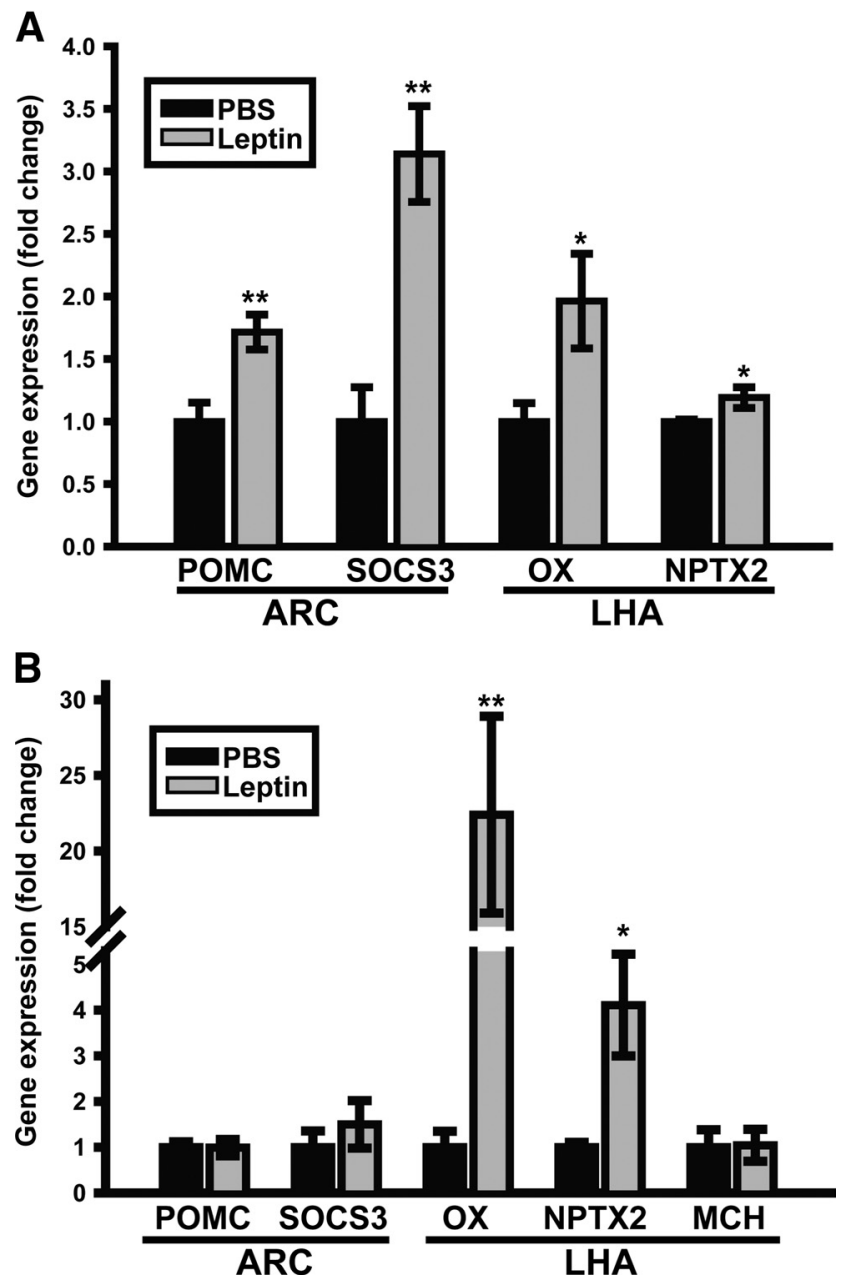

Figure 7. Changes in gene expression after systemic and local leptin treatment in Lep $p^{o b / o b}$ $(o b / o b)$ mice. Changes in gene expression in microdissected tissue of ARC or LHA from Lep ${ }^{o b / o b}$ mice after $26 \mathrm{~h}$ systemic $(5 \mathrm{mg} / \mathrm{kg}$, i.p.) $(\boldsymbol{A})$ or intra-LHA $(0.25 \mathrm{ng})(\boldsymbol{B})$ treatment with PBS (black bars) or leptin (gray bars). Expression data are plotted relative to Gapdh expression (calculated by $2^{-\Delta \Delta \text { (t }}$ method) and normalized to control (PBS-treated) levels and contralateral sides (for intra-LHA group) \pm SEM. ${ }^{*} p<0.05,{ }^{* *} p<0.01$ relative to PBS.

VTA LepRb neurons densely innervate the CeA (central nucleus of the amygdala), where they innervate and regulate CART (cocaine- and amphetamine-regulated transcript)-expressing neurons (Leshan et al., 2010).

The strength with which local LHA leptin promotes $O x$ and Narp mRNA expression compared with that observed in response to systemic leptin (along with the paucity of projections to the OX field from other populations of LepRb neurons) suggests that LHA LepRb neurons likely represent the main neural mediators of leptin action on OX neurons. Although the technical difficulties associated with measuring c-fos (a surrogate for neuronal activity) in the region surrounding a cannula prevented us from examining the regulation of OX neuron activity in response to LHA leptin, the lack of significant LepRb projections to this region from elsewhere and the GABAergic nature of the LHA LepRb neurons (Leinninger et al., 2009) prompts us to hypothesize that LHA LepRb neurons might inhibit the activity of OX neurons, as well as controlling their gene expression.

Although it is clear from our present observations that $\mathrm{MCH}$ neurons lie in synaptic contact with LepRb neurons, the lack of WGA accumulation in $\mathrm{MCH}$ neurons after intra-LHA injection of Ad-iN/WED in LepRb ${ }^{\text {cre }}$ mice reveals that the LepRb neurons that project onto MCH neurons likely lie outside of the LHA. The population of LepRb neurons that lie upstream of $\mathrm{MCH}$ neurons thus remains unidentified, although a variety of previously published data suggest a potential role for ARC melanocortin neurons in this regulation (Hanada et al., 2000). Tracing from the larger LHA (not specifically the dorsal perifornical area), Elias et al. (1998) revealed a population of leptin-activated ARC neurons projecting to the LHA. In addition, our analysis of FG labeling from the LHA region where MCH neurons are located, lateral to the OX field, revealed potential projections from LepRb populations in the ARC (as well as the NTS and DR). Indeed, Mch expression is increased in mice overexpressing the melanocortin antagonist, Agouti (although $O x$ is not altered); also, melanocortin agonists/antagonists regulate Mch expression (Hanada et al., 2000; Tritos et al., 2001; Morton et al., 2004; Kim et al., 2005). Our present data also reveal that other LHA neurons receive input from LHA LepRb neurons, based on their accumulation of WGA. Although markers are not available to identify the likely subpopulations of these, we speculate based on the small size of many of these cells that they may represent GABAergic interneurons.

Our present data demonstrating the regulation of OX neurons by LHA LepRb neurons suggests important roles for these LHA LepRb neurons in energy balance and in CNS leptin action. Although acute injection of OX into the CNS promotes activity, wakefulness, and hyperphagia, the long-term role of $\mathrm{OX}$ is to promote activity and energy expenditure, while decreasing feeding (Tritos et al., 2001; Mieda and Yanagisawa, 2002; Yamanaka et al., 2003; Funato et al., 2009). Indeed, mice (and humans) null for OX are obese, whereas widespread overexpression of OX promotes leanness (Sakurai et al., 1998; Chemelli et al., 1999; Hara et al., 2001; Funato et al., 2009). Much of this OX action on energy balance depends on the OX2R, as mice null for this receptor demonstrate increased feeding and become more obese than controls on a high fat diet; systemic treatment with an OX2R agonist prevents diet-induced obesity (Funato et al., 2009). Presumably, therefore, the acute effects of OX may be mimicked by increased activity of OX neurons during food restriction (which is blunted by leptin), whereas the increased expression of $O x$ promoted by leptin (via LHA LepRb neurons) would be expected to promote the kind of chronic OX effects required for leptin action. Indeed, we previously showed that intra-LHA leptin decreased feeding and body weight over $24 \mathrm{~h}$ in $\mathrm{Lep}^{o b / o b}$ animals (Leinninger et al., 2009). Unfortunately, acute treatment with systemic OXR antagonists inhibits movement and blunts feeding (data not shown), and the determination of roles for OX in physiologic actions downstream of the LHA LepRb neurons will require circuitspecific manipulation.

Our previous analysis of LHA LepRb neurons also identified projections from these neurons to the VTA, and revealed that LHA leptin treatment of $L e p^{o b / o b}$ animals promotes VTA Th expression and increased DA content in the NAc (nucleus accumbens) (Leinninger et al., 2009). Our present findings that LHA LepRb neurons project onto and regulate OX neurons, which themselves innervate the VTA to modulate the actions of the mesolimbic DA system (Nakamura et al., 2000; Baldo et al., 2003; Harris et al., 2005; Kelley et al., 2005; Narita et al., 2006), suggests that LHA LepRb neurons may modulate the mesolimbic DA system indirectly, via OX neurons, as well as by direct projection to the VTA. Although outside the scope of this study, it will be important to dissect the relative contributions of these direct and indirect pathways from LHA LepRb neurons to the mesolimbic DA system and energy balance. 


\section{References}

Allen T, van Tuyl M, Iyengar P, Jothy S, Post M, Tsao MS, Lobe CG (2006) Grg1 acts as a lung-specific oncogene in a transgenic mouse model. Cancer Res 66:1294-1301.

Baldo BA, Daniel RA, Berridge CW, Kelley AE (2003) Overlapping distributions of orexin/hypocretin- and dopamine-beta-hydroxylase immunoreactive fibers in rat brain regions mediating arousal, motivation, and stress. J Comp Neurol 464:220-237.

Balthasar N, Coppari R, McMinn J, Liu SM, Lee CE, Tang V, Kenny CD, McGovern RA, Chua SC Jr, Elmquist JK, Lowell BB (2004) Leptin receptor signaling in POMC neurons is required for normal body weight homeostasis. Neuron 42:983-991.

Banks AS, Davis SM, Bates SH, Myers MG Jr (2000) Activation of downstream signals by the long form of the leptin receptor. J Biol Chem 275:14563-14572.

Bates SH, Stearns WH, Dundon TA, Schubert M, Tso AW, Wang Y, Banks AS, Lavery HJ, Haq AK, Maratos-Flier E, Neel BG, Schwartz MW, Myers MG Jr (2003) STAT3 signaling is required for leptin regulation of energy balance but not reproduction. Nature 421:856-859.

Bjorbak C, Lavery HJ, Bates SH, Olson RK, Davis SM, Flier JS, Myers MG Jr (2000) SOCS3 mediates feedback inhibition of the leptin receptor via Tyr985. J Biol Chem 275:40649-40657.

Braz JM, Rico B, Basbaum AI (2002) Transneuronal tracing of diverse CNS circuits by Cre-mediated induction of wheat germ agglutinin in transgenic mice. Proc Natl Acad Sci U S A 99:15148-15153.

Chemelli RM, Willie JT, Sinton CM, Elmquist JK, Scammell T, Lee C, Richardson JA, Williams SC, Xiong Y, Kisanuki Y, Fitch TE, Nakazato M, Hammer RE, Saper CB, Yanagisawa M (1999) Narcolepsy in orexin knockout mice: molecular genetics of sleep regulation. Cell 98:437-451.

Cohen P, Zhao C, Cai X, Montez JM, Rohani SC, Feinstein P, Mombaerts P, Friedman JM (2001) Selective deletion of leptin receptor in neurons leads to obesity. J Clin Invest 108:1113-1121.

de Luca C, Kowalski TJ, Zhang Y, Elmquist JK, Lee C, Kilimann MW, Ludwig T, Liu SM, Chua SC Jr (2005) Complete rescue of obesity, diabetes, and infertility in $\mathrm{db} / \mathrm{db}$ mice by neuron-specific LEPR-B transgenes. J Clin Invest 115:3484-3493.

Dhillon H, Zigman JM, Ye C, Lee CE, McGovern RA, Tang V, Kenny CD, Christiansen LM, White RD, Edelstein EA, Coppari R, Balthasar N, Cowley MA, Chua S Jr, Elmquist JK, Lowell BB (2006) Leptin directly activates SF1 neurons in the $\mathrm{VMH}$, and this action by leptin is required for normal body-weight homeostasis. Neuron 49:191-203.

DiLeone RJ, Georgescu D, Nestler EJ (2003) Lateral hypothalamic neuropeptides in reward and drug addiction. Life Sci 73:759-768.

Donato J Jr, Silva RJ, Sita LV, Lee S, Lee C, Lacchini S, Bittencourt JC, Franci CR, Canteras NS, Elias CF (2009) The ventral premammillary nucleus links fasting-induced changes in leptin levels and coordinated luteinizing hormone secretion. J Neurosci 29:5240-5250.

Elias CF, Saper CB, Maratos-Flier E, Tritos NA, Lee C, Kelly J, Tatro JB, Hoffman GE, Ollmann MM, Barsh GS, Sakurai T, Yanagisawa M, Elmquist JK (1998) Chemically defined projections linking the mediobasal hypothalamus and the lateral hypothalamic area. J Comp Neurol 402:442-459.

Elmquist JK, Bjørbaek C, Ahima RS, Flier JS, Saper CB (1998) Distributions of leptin receptor mRNA isoforms in the rat brain. J Comp Neurol 395:535-547.

Elmquist JK, Coppari R, Balthasar N, Ichinose M, Lowell BB (2005) Identifying hypothalamic pathways controlling food intake, body weight, and glucose homeostasis. J Comp Neurol 493:63-71.

Figlewicz DP, MacDonald Naleid A, Sipols AJ (2007) Modulation of food reward by adiposity signals. Physiol Behav 91:473-478.

Friedman JM (2002) The function of leptin in nutrition, weight, and physiology. Nutr Rev 60:S1-S14.

Fulton S, Pissios P, Manchon RP, Stiles L, Frank L, Pothos EN, Maratos-Flier E, Flier JS (2006) Leptin regulation of the mesoaccumbens dopamine pathway. Neuron 51:811-822.

Funato H, Tsai AL, Willie JT, Kisanuki Y, Williams SC, Sakurai T, Yanagisawa M (2009) Enhanced orexin receptor-2 signaling prevents diet-induced obesity and improves leptin sensitivity. Cell Metab 9:64-76.

Grill HJ (2006) Distributed neural control of energy balance: contributions from hindbrain and hypothalamus. Obesity (Silver Spring) 14 [Suppl 5]:216S-221S.

Hanada R, Nakazato M, Matsukura S, Murakami N, Yoshimatsu H, Sakata T
(2000) Differential regulation of melanin-concentrating hormone and orexin genes in the agouti-related protein/melanocortin-4 receptor system. Biochem Biophys Res Commun 268:88-91.

Hanno Y, Nakahira M, Jishage K, Noda T, Yoshihara Y (2003) Tracking mouse visual pathways with WGA transgene. Eur J Neurosci 18:29102914.

Hara J, Beuckmann CT, Nambu T, Willie JT, Chemelli RM, Sinton CM, Sugiyama F, Yagami K, Goto K, Yanagisawa M, Sakurai T (2001) Genetic ablation of orexin neurons in mice results in narcolepsy, hypophagia, and obesity. Neuron 30:345-354.

Harris GC, Wimmer M, Aston-Jones G (2005) A role for lateral hypothalamic orexin neurons in reward seeking. Nature 437:556-559.

Hommel JD, Trinko R, Sears RM, Georgescu D, Liu ZW, Gao XB, Thurmon JJ, Marinelli M, DiLeone RJ (2006) Leptin receptor signaling in midbrain dopamine neurons regulates feeding. Neuron 51:801-810.

Jo YH, Chen YJ, Chua SC Jr, Talmage DA, Role LW (2005) Integration of endocannabinoid and leptin signaling in an appetite-related neural circuit. Neuron 48:1055-1066.

Kelley AE, Baldo BA, Pratt WE (2005) A proposed hypothalamic-thalamicstriatal axis for the integration of energy balance, arousal, and food reward. J Comp Neurol 493:72-85.

Kim RY, Shin SW, Kim BJ, Lee W, Baik JH (2005) Dynamic regulation of hypothalamic neuropeptide gene expression and food intake by melanocortin analogues and reversal with melanocortin-4 receptor antagonist. Biochem Biophys Res Commun 329:1178-1185.

Leinninger GM, Jo YH, Leshan RL, Louis GW, Yang H, Barrera JG, Wilson H, Opland DM, Faouzi MA, Gong Y, Jones JC, Rhodes CJ, Chua S Jr, Diano S, Horvath TL, Seeley RJ, Becker JB, Münzberg H, Myers MG Jr (2009) Leptin acts via leptin receptor-expressing lateral hypothalamic neurons to modulate the mesolimbic dopamine system and suppress feeding. Cell Metab 10:89-98.

Leshan RL, Louis GW, Jo YH, Rhodes CJ, Münzberg H, Myers MG Jr (2009) Direct innervation of GnRH neurons by metabolic- and sexual odorantsensing leptin receptor neurons in the hypothalamic ventral premammillary nucleus. J Neurosci 29:3138-3147.

Leshan RL, Opland DM, Louis GW, Leinninger GM, Patterson CM, Rhodes CJ, Münzberg H, Myers MG Jr (2010) Ventral tegmental area leptin receptor neurons specifically project to and regulate cocaine- and amphetamine-regulated transcript neurons of the extended central amygdala. J Neurosci 30:5713-5723.

Mieda M, Yanagisawa M (2002) Sleep, feeding, and neuropeptides: roles of orexins and orexin receptors. Curr Opin Neurobiol 12:339-345.

Morton GJ, Niswender KD, Rhodes CJ, Myers MG Jr, Blevins JE, Baskin DG, Schwartz MW (2003) Arcuate nucleus-specific leptin receptor gene therapy attenuates the obesity phenotype of Koletsky $\left(f a^{k} / f a^{k}\right)$ rats. Endocrinology 144:2016-2024.

Morton GJ, Mystkowski P, Matsumoto AM, Schwartz MW (2004) Increased hypothalamic melanin concentrating hormone gene expression during energy restriction involves a melanocortin-independent, estrogen-sensitive mechanism. Peptides 25:667-674.

Morton GJ, Cummings DE, Baskin DG, Barsh GS, Schwartz MW (2006) Central nervous system control of food intake and body weight. Nature 443:289-295

Münzberg H, Jobst EE, Bates SH, Jones J, Villanueva E, Leshan R, Björnholm M, Elmquist J, Sleeman M, Cowley MA, Myers MG Jr (2007) Appropriate inhibition of orexigenic hypothalamic arcuate nucleus neurons independently of leptin receptor/STAT3 signaling. J Neurosci 27: $69-74$.

Myers MG Jr, Münzberg H, Leinninger GM, Leshan RL (2009) The geometry of leptin action in the brain: more complicated than a simple ARC. Cell Metab 9:117-123.

Nakamura T, Uramura K, Nambu T, Yada T, Goto K, Yanagisawa M, Sakurai $\mathrm{T}$ (2000) Orexin-induced hyperlocomotion and stereotypy are mediated by the dopaminergic system. Brain Res 873:181-187.

Narita M, Nagumo Y, Hashimoto S, Narita M, Khotib J, Miyatake M, Sakurai T, Yanagisawa M, Nakamachi T, Shioda S, Suzuki T (2006) Direct involvement of orexinergic systems in the activation of the mesolimbic dopamine pathway and related behaviors induced by morphine. J Neurosci 26:398-405.

Nestler EJ (2005) Is there a common molecular pathway for addiction? Nat Neurosci 8:1445-1449.

Qu D, Ludwig DS, Gammeltoft S, Piper M, Pelleymounter MA, Cullen MJ, 
Mathes WF, Przypek R, Kanarek R, Maratos-Flier E (1996) A role for melanin-concentrating hormone in the central regulation of feeding behavior. Nature 380:243-247.

Reti IM, Reddy R, Worley PF, Baraban JM (2002) Selective expression of Narp, a secreted neuronal pentraxin, in orexin neurons. J Neurochem 82:1561-1565.

Sakurai T, Amemiya A, Ishii M, Matsuzaki I, Chemelli RM, Tanaka H, Williams SC, Richarson JA, Kozlowski GP, Wilson S, Arch JR, Buckingham RE, Haynes AC, Carr SA, Annan RS, McNulty DE, Liu WS, Terrett JA, Elshourbagy NA, Bergsma DJ, et al. (1998) Orexins and orexin receptors: a family of hypothalamic neuropeptides and G protein-coupled receptors that regulate feeding behavior. Cell 92:1 page following 696.

Scott MM, Lachey JL, Sternson SM, Lee CE, Elias CF, Friedman JM, Elmquist JK (2009) Leptin targets in the mouse brain. J Comp Neurol 514:518532.

Sharf R, Sarhan M, Dileone RJ (2010) Role of orexin/hypocretin in dependence and addiction. Brain Res 1314:130-138.

Soliman GA, Ishida-Takahashi R, Gong Y, Jones JC, Leshan RL, Saunders TL,
Fingar DC, Myers MG Jr (2007) A simple qPCR-based method to detect correct insertion of homologous targeting vectors in murine ES cells. Transgenic Res 16:665-670.

Tritos NA, Mastaitis JW, Kokkotou E, Maratos-Flier E (2001) Characterization of melanin concentrating hormone and preproorexin expression in the murine hypothalamus. Brain Res 895:160-166.

van de Wall E, Leshan R, Xu AW, Balthasar N, Coppari R, Liu SM, Jo YH, MacKenzie RG, Allison DB, Dun NJ, Elmquist J, Lowell BB, Barsh GS, de Luca C, Myers MG Jr, Schwartz GJ, Chua SC Jr (2008) Collective and individual functions of leptin receptor modulated neurons controlling metabolism and ingestion. Endocrinology 149:1773-1785.

Yamanaka A, Beuckmann CT, Willie JT, Hara J, Tsujino N, Mieda M, Tominaga M, Yagami K, Sugiyama F, Goto K, Yanagisawa M, Sakurai T (2003) Hypothalamic orexin neurons regulate arousal according to energy balance in mice. Neuron 38:701-713.

Zylka MJ, Rice FL, Anderson DJ (2005) Topographically distinct epidermal nociceptive circuits revealed by axonal tracers targeted to Mrgprd. Neuron $45: 17-25$. 